\title{
PRODUCTION, DECOMPOSITION AND CHEMICAL CHARACTERISTICS OF BANANA LITTERFALL ${ }^{1}$
}

\author{
CLEITON FERNANDO BARBOSA BRITO ${ }^{2}$, VARLEY ANDRADE FONSECA ${ }^{2 *}$, FELIZARDA VIANA BEBÉ $^{2}$, \\ ALESSANDRE GABRIEL OLIVEIRA RAMOS ${ }^{2}$, GEORGE BRITO SILVA ${ }^{3}$
}

\begin{abstract}
The characterization of litterfall in forest and agroforest systems is important to better understand the cycling of nutrients, however, few studies on litterfall of fruit trees, such as banana, are found. Therefore, the objective of this work was assess the production and decomposition and chemically characterize the litterfall of banana genotypes cropped in a dystrophic typical Red-Yellow Latossol, with weak A horizon, medium texture in a hypo-xerophytic Caatinga in the Southwest of Bahia, Brazil. A completely randomized experimental design was used, with twelve treatments (genotypes) and five replications. The genotypes Preciosa, Pacovan-Ken and Maravilha presented the greatest dry weight. The genotype Fhial 8 showed the longest half-life of litterfall decomposition. The banana genotypes Preciosa, Maravilha and Pacovan-Ken produce the greatest contents of litterfall, and their chemical characterization shows the descending order $\mathrm{Ca}>\mathrm{N}>\mathrm{Mg}>\mathrm{K}>\mathrm{S}>\mathrm{P}$ for macronutrients and $\mathrm{Fe}>\mathrm{Mn}>\mathrm{B}>\mathrm{Zn}>\mathrm{Cu}$ for micronutrients. The banana genotypes PV-79-34, Garantida, Pacovan, JV-42-135, Prata-Anã, Pacovan-Ken, Preciosa and Maravilha present the lowest number of days for decomposition of the litterfall accumulated.
\end{abstract}

Keywords: Musa spp.. Nutrient cycling. Plant nutrition.

\section{PRODUÇÃO, DECOMPOSIÇÃo E CARACTERIZAÇÃo QUÍMICA DA SERAPILHEIRA DE BANANEIRA}

RESUMO - A caracterização da serapilheira em sistemas florestais e agroflorestais mostra-se importante no entendimento da ciclagem de nutrientes, no entanto, estudos em frutíferas, como a bananeira, ainda são escassos. Objetivou-se determinar a produção, decomposição e caracterização química da serapilheira em genótipos de bananeira no Sudoeste Baiano em Latossolo Vermelho Amarelo distrófico típico, com horizonte A fraco, textura média, fase caatinga hipoxerófila. $\mathrm{O}$ delineamento experimental utilizado foi inteiramente casualizado, constituído de doze tratamentos (genótipos) e cinco repetições. Os genótipos Preciosa, Pacovan-Ken e Maravilha, apresentaram as maiores produções de massa seca. Para decomposição de 50 \% da massa seca da serapilheira, observou-se que o genótipo Fhia18 apresentou o maior tempo de decomposição. Os genótipos Preciosa, Maravilha e Pacovan-Ken apresentam maiores produções de serapilheira com caracterização química em ordem crescente para os macronutrientes $\mathrm{Ca}>\mathrm{N}>\mathrm{Mg}>\mathrm{K}>\mathrm{S}>\mathrm{P}$ e micronutrientes $\mathrm{Fe}>\mathrm{Mn}>\mathrm{B}>\mathrm{Zn}>\mathrm{Cu}$. Os genótipos PV-79-34, Garantida, Pacovan, JV-42-135, Prata-Anã, Pacovan-Ken, Preciosa, Maravilha apresenta menores números de dias para decomposição da serapilheira acumulada.

Palavras-chave: Musa spp.. Restituição de nutrientes. Nutrição de plantas. 


\section{INTRODUCTION}

Banana (Musa spp.) crops have great socio-economic importance for the producing countries. This fruit is grown in various tropical regions, with India, Uganda, the Philippines, China, Ecuador and Brazil accounting for about $60 \%$ of world production (FAO, 2014).

Plant breeding programs of banana began to select new genotypes with superior characteristics and recommend cultivars, mainly, due to phytosanitary problems. In this regard, several studies with field evaluations were performed on agronomic performance of different banana genotypes (DONATO et al., 2009; AZEVEDO et al., 2010).

Moreover, studies on accumulation and chemical characterization of litterfall of different banana genotypes are also important, since this plant accumulates greater amounts of dry matter and nutrients in its vegetative organs and fruits, which return to the system as plant residues (stem, fruits, leaves, floral residues and pseudo-stem) produced during its cycle (HOFFMANN et al., 2010a; MOREIRA; FAGERIA, 2009).

Researches on production, decomposition and chemical characterization of litterfall are mainly conducted in forest and agroforest systems (BRUN; FERRAZ; ARAÚJO, 2013; SILVA et al., 2014; LOPES; ARAÚJO; VASCONCELLOS, 2013; OZIEGBE; MUOGHALU; OKE , 2011). Studies on litterfall from cultivated fruit trees, such as banana, are not found in the literature.

Pereira et al. (2012) reported annual average production of litterfall of $7.64 \mathrm{Mg} \mathrm{ha}^{-1}$ in a forest system, with a half-life of litterfall decomposition of 462 days. A similar research showed a production of $8.6 \mathrm{Mg} \mathrm{ha}^{-1}$ and a half-life of litterfall decomposition of 495 (WHITE et al., 2013).

Forest systems present ascending order $\mathrm{Ca}>\mathrm{N}>\mathrm{K}>\mathrm{Mg}>\mathrm{P}$ for macronutrients (PIMENTA et al., 2011). Nutrient availability in litterfall depends, mainly, on its chemical composition and the plant structure (VIERA et al., 2010). Thus, the results of the production, decomposition and chemical characterization of the litterfall of banana could be parameters for selection of new banana cultivars at field evaluation phases.

The litterfall production, considering all its forming fractions, which vary in plant species, and its incorporation to the soil and decomposition form the effective return of nutrients to the soil, which is one of the most important processes in nutrient cycling of production systems (WHITE et al., 2013; TERROR; SOUSA; KOZOVITS, 2011).

The process of nutrient release by decomposition is related to several factors, however, the material quality significantly contributes to the nutrient cycling (TANGJANG et al., 2015).

Therefore, the objective of this work was assess the production, decomposition and chemically characterize the litterfall of banana genotypes in the Southwest of Bahia, Brazil.

\section{MATERIAL AND METHODS}

The experiment was conducted in the experimental area of the Federal Institute of Education, Science and Technology of Bahia, Guanambi campus, State of Bahia, Brazil. The area was in a hypo-xerophytic Caatinga and had a dystrophic typical Red-Yellow Latossol, with weak A horizon, medium texture, chemical characterization according to the Table 1, plain to soft-wavy relief and altitude of $537 \mathrm{~m}$. The region climate is Aw, according to the Köppen classification, with annual average precipitation of $664 \mathrm{~mm}$ and annual average temperature of $26^{\circ} \mathrm{C}$ (DONATO et al., 2010). The precipitation and the maximum, medium and minimum temperatures in the experimental period are showed in Figure 1.

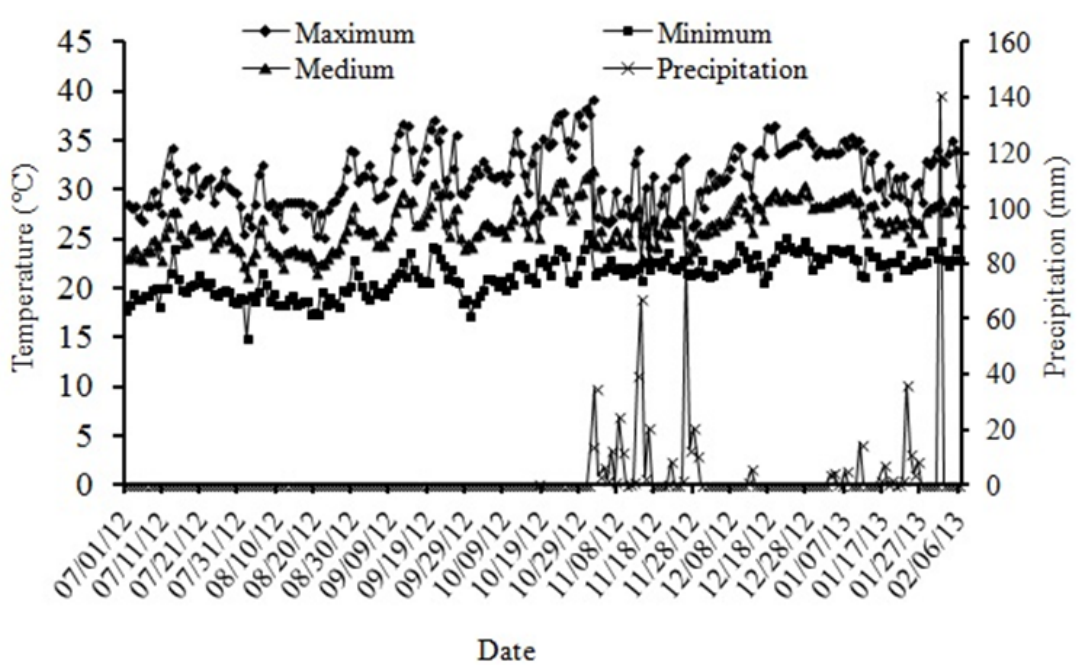

Figure 1. Maximum, medium and minimum temperatures and precipitation during the experiment, measured by an automatic station. 
C. F. B. BRITO et al.

Table 1. Soil chemical characterization of the experimental area.

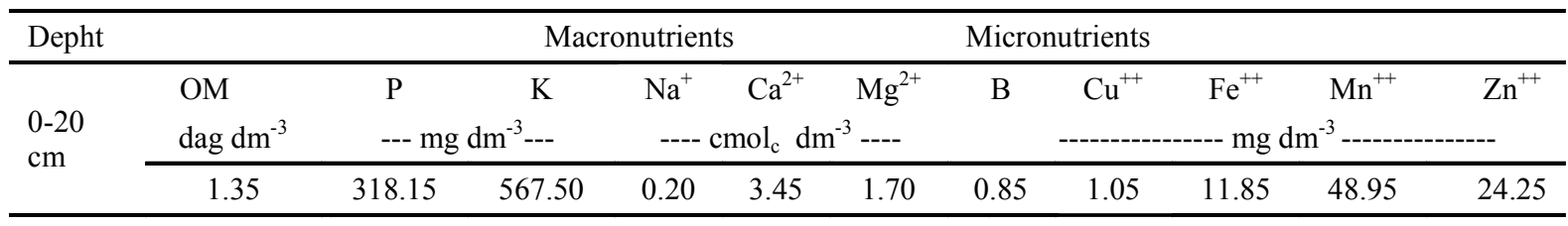

$\mathrm{P}, \mathrm{K}, \mathrm{Na}, \mathrm{Cu}, \mathrm{Fe}, \mathrm{Mn}, \mathrm{Zn}$ extract by Mehlich-1; Ca, Mg extracted by $\mathrm{KCl} 1 \mathrm{~mol} \mathrm{~L}{ }^{-1}$; B extracted by hot water; OM: organic matter.

Micropropagated banana seedlings were planted, with spacing of $3.0 \times 2.5 \mathrm{~m}$, and cultural practices were performed according to the recommendations for the crop. A micro-sprinkler system was used to irrigate the plants, using pressure compensating emitters (Netafim $\left.{ }^{\circledR}\right)$, flow of $120 \mathrm{~L} \mathrm{~h}^{-1}$, with spacing of $6 \mathrm{~m}$ between side lines and $5 \mathrm{~m}$ between emitters.

A completely randomized experimental design was used, with twelve treatments (genotypes), five replications and four plants per plot. The genotypes used were Prata-Anã (AAB), Fhia-01 (Maravilha, AAAB), Fhia-18 (BRS Fhia-18, AAAB), PA42-44 (AAAB), PA94-01 (Fhia-18, AAAB), JV42-135 (AAAB), Pacovan (AAB), PV42-142 (Japira, AAAB), PV79-34 (AAAB), PV42-68 (Pacovan-Ken, AAAB), PV42-85 (Preciosa, AAAB) and ST42-08 (Garantida, AAAB).

A collection was performed at the end of each crop cycle to quantify the total litterfall produced by the different banana genotypes. One wood box $(1.00 \times 1.00 \times 0.15 \mathrm{~m})$, with bottom made of a 1 mm-mesh polypropylene shade-cloth, were placed directly on the ground, randomly distributed between the four plants evaluated of each plot, totaling five boxes for each genotype (ALVES et al., 2006). The boxes were placed in the plots six months before the end of the crop cycle.

The amount of accumulated litterfall on the soil surface was estimated by quarterly collections of all material on a square frame $(0.5 \mathrm{x} 0.5 \mathrm{~m})$ released randomly in the area, with five replications (GAMA-RODRIGUES; BARROS, 2002).

The litterfall collected in the wood box of each experimental plot was dried in an oven at $65^{\circ} \mathrm{C}$ and weighed. The dry material was ground in a Wiley mill and sieved in a $1 \mathrm{~mm}$-mesh sieve, resulting in single samples for subsequent digestion in a nitro-perchloric acid solution (MALAVOLTA; VITTI; OLIVEIRA, 1997). P, K, Ca, Mg, Cu, Fe, $\mathrm{Mn}, \mathrm{Zn}, \mathrm{B}, \mathrm{S}$ and $\mathrm{Na}$ contents were evaluated in the extract by an atomic absorption spectrophotometer. Sulfuric digestion was used for analysis of total N. The amount of nutrients that returned to the soil was assessed by multiplying the nutrient concentration by the dry weight of the litterfall collected in the square frame.

The estimation of the litterfall decomposition rate was assessed by the equation proposed by Olson (1963), used in similar studies (ARATO, et al., 2003): $K=L / X$, where $K=$ decomposition coefficient, $L=$ litterfall annual production and $X=$ annual average of accumulated litterfall. The half-life of litterfall decomposition was estimated by the equation of Shanks and Olson (1961): $T 0.5=-\ln 0.5 / K$.

The results were subjected to analysis of variance and the averages were grouped by the Scott-Knott criterion, at 5\% of probability, using the statistical software R, (R DEVELOPMENT CORE TEAM, 2012).

\section{RESULTS AND DISCUSSION}

The litterfall dry weight found formed two groups by the Scott-Knott criterion, at 5\% of probability (Figure 2), one formed by the genotypes with the greatest productions: Preciosa $\left(14,964.96 \mathrm{~kg} \mathrm{ha}^{-1}\right)$, Maravilha $\left(13,981.52 \mathrm{~kg} \mathrm{ha}^{-1}\right)$ and Pacovan-Ken $\left(13,453.80 \mathrm{~kg} \mathrm{ha}^{-1}\right)$, and other formed by the remaining genotypes. These differences may be related to morphological characteristics (height, pseudostem length, leaf area), productivity and vigor of each genotype and their environment. These differences may be taken into account for fertilizer recommendation for banana crops, since these residues left in the soil contain great nutrient contents that can be mineralized and absorbed by plants (cycling).

Hoffmann et al. (2010a) evaluated the dry weight accumulation and macronutrients for banana cultivars and found dry weight values of 28,398 (Pacovan) 17,715 (Pacovan Apodi) and $20,077 \mathrm{~kg} \mathrm{ha}^{-1}$ (Prata-Anã), which were higher than those found in the present work because they included the fruit and stem dry weights, while the present work considered the pseudostem, leaves and floral residues. 
These results indicate that the pseudostem greatly contribute to the total dry weight of banana. Soares et al. (2011) evaluated the accumulation of dry weight and distribution of nutrients of two banana cultivars irrigated with brackish water and found dry weight of bunch, leaves and rhizome (35.1, 29.6 and $17.3 \%$, respectively) lower than the pseudostem.

Azevedo et al. (2010) evaluated banana Prata in semiarid conditions and found the genotype PV79-34 with the lowest heights, Pacovan with intermediate height, the other Pacovan hybrids (Pacovan-Ken, Japira, PV42-53 and Preciosa) with high heights, the genotypes Preciosa, PV79-34, Pacovan-Ken, and Garantida with the largest pseudostem perimeters, and the Pacovan and Japira with the shortest. The genotypes that had the highest height and larger pseudostem perimeter (Preciosa and Pacovan-Ken) in their study were in the greatest dry weight group in the present study. This result indicates that genotypes that have high heights and large pseudostem perimeter tend to have greater dry weight.

The genotypes Fhia-18 and PA-9401 showed lower height, which probably contributed to group them in the low dry weight group. Genotypes of larger size presented higher yields, however, in area with strong wind conditions, as found in the present study, high heights can lead to the toppling of banana trees, thus, genotypes of smaller size are indicated for these areas.

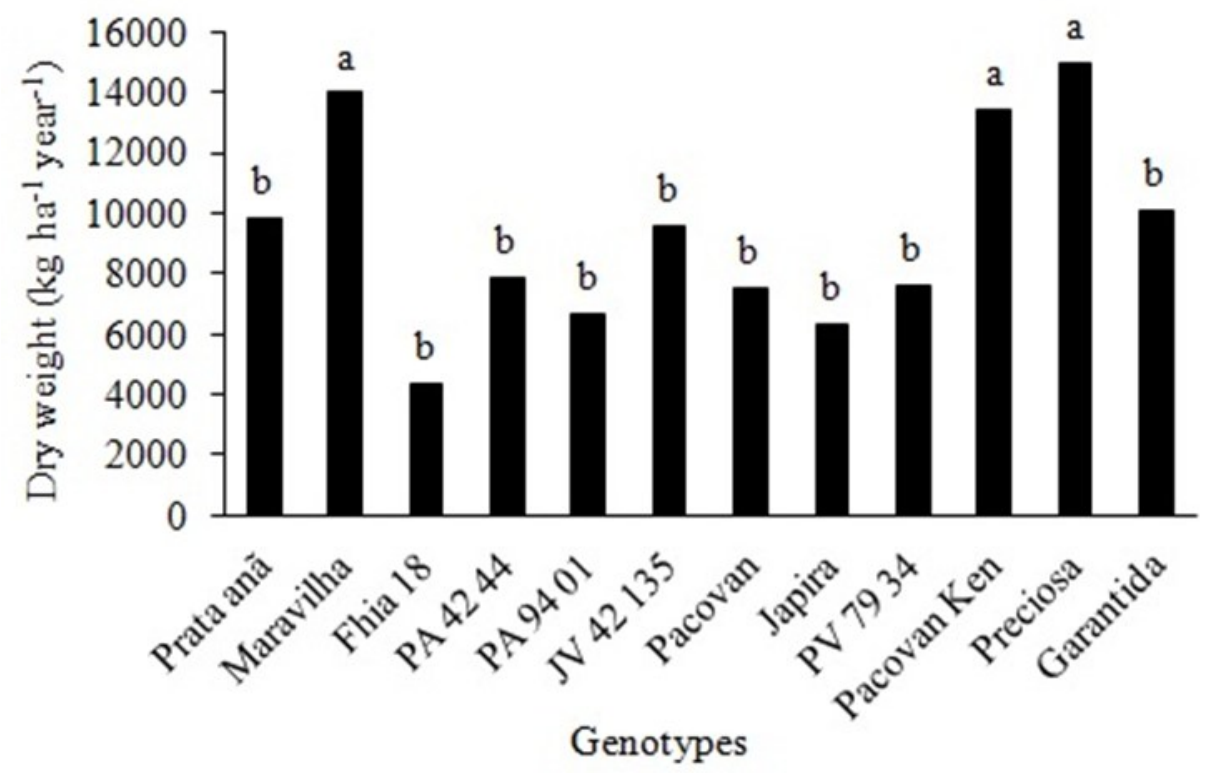

Means followed by the same letters are from to the same group by the Scott-Knott criterion at $5 \%$ of probability.

Figure 2. Litterfall dry weight of banana genotypes.

The half-life of litterfall decomposition (days) formed three groups of genotypes, representing the high, intermediate and low number of days for decomposition: 1- Fhia-18 (359), 2- PA94-01 (256), Japira (236) and PA-4244 (224), and 3) PV79-34 (203), Garantida (186), Pacovan (176), JV42-135 (172), Prata-Anã (141), Pacovan-Ken (122), Preciosa (118) and Maravilha (97) (Figure 3). The results showed that the higher the dry weight, the lower the number of days for decomposition (Figure 2).

A great amount of dry matter on the soil under irrigated banana favors the microbiota development, which is responsible for the decomposition of plant debris, by produce a favorable microclimate due to the constant moisture. Thus, the greater the dry matter amount, the faster the decomposition process. Small amounts of residues make the soil exposed to solar radiation, promoting adverse conditions for development of decomposing agents, as observed in genotypes Fhia-18, PA94-01 and Japira, which had low dry matter and longer decomposition.

Genotypes with intermediate half-life of litterfall decomposition, around 230 days (Figure 3) were similar to the time found by Arato et al. (2003) (215 days) in an agroforestry system containing banana between other fruit plants. A shorter time for litterfall decomposition favors the mineralization of nutrients which are reused by the banana trees. 


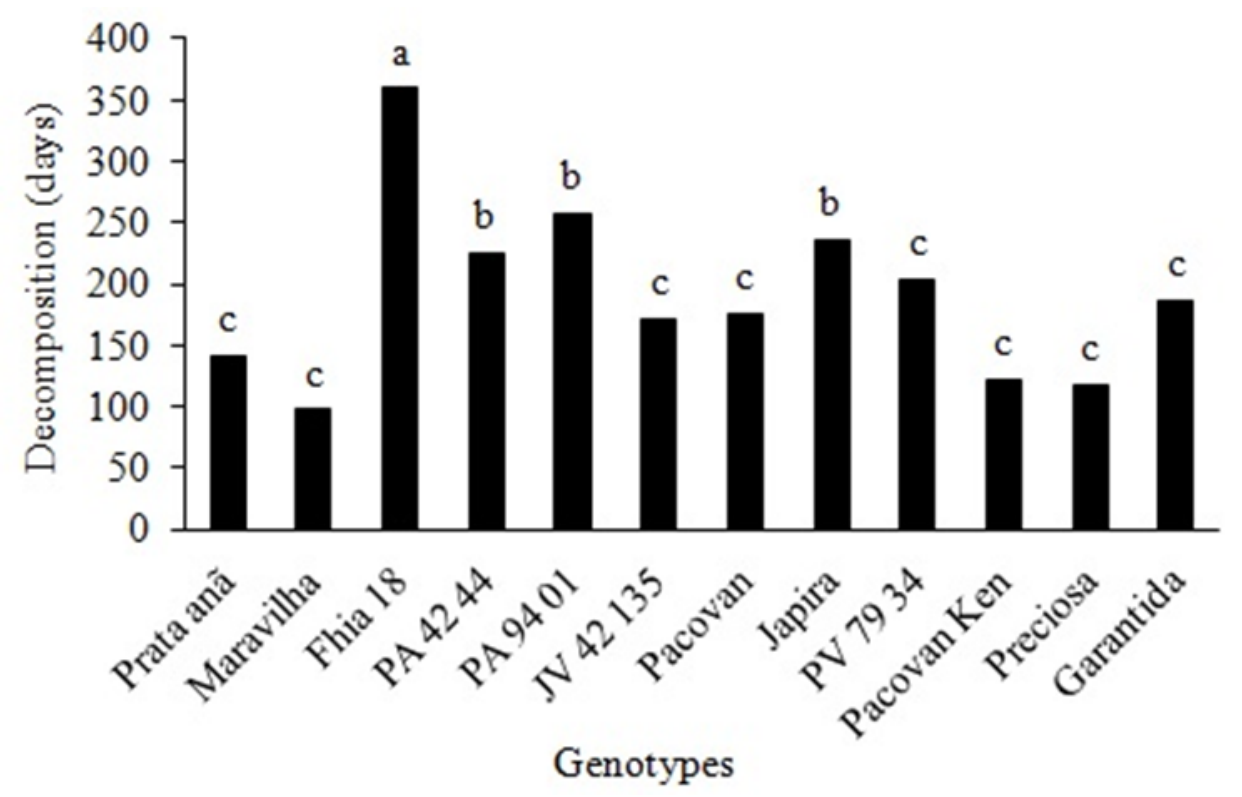

Means followed by the same letters are from to the same group by the Scott-Knott criterion at $5 \%$ of probability.

Figure 3. Estimated half-life of litterfall decomposition of banana genotypes.

The estimates of the amounts of macronutrients in the litterfall formed groups, which confirms that the genotypes return to the soil different amounts of macronutrients (Table 2). The estimated means of $\mathrm{N}$ (nitrogen) and $\mathrm{P}$ (phosphorus) in the litterfall ranged from 24.69 (Fhia-18) to 70.99 (Preciosa) kg ha-1 and 2.19 (Fhia-18) to 7.45 (Preciosa) $\mathrm{kg} \mathrm{ha}^{-1}$, respectively, forming two groups by the Scott-Knott criterion at $5 \%$ of probability (Table 2). The genotypes Preciosa, Pacovan-Ken and Maravilha had the greatest amounts of $\mathrm{N}$ and $\mathrm{P}$ compared to the others. The leaf fraction was probably the one that most contributed for the $\mathrm{N}$ contents. Moreira and Fageria (2009) studied the distribution and remobilization of nutrients in crop residues of banana and found $\mathrm{P}$ content of $28.7 \mathrm{~kg} \mathrm{ha}^{-1}$. Thus, the incorporation of plant residues is very important to maximize the availability of $P$ for plants.

The genotypes Prata-Anã, Maravilha, Pacovan, Japira, Pacovan-Ken and Preciosa grouped with the largest amounts of K (Potassium) return to the soil, while the other genotypes were grouped with the smallest amounts. The third most accumulated nutrient in the litterfall was $\mathrm{K}$, which is considered an important element for the banana nutrition, acting directly in several functions, photosynthesis, gas exchange, photosynthate translocations and turgidity of the plant (MALAVOLTA, 2006). It is the banana most absorbed nutrient, however, much of the absorbed $\mathrm{K}$ is exported in the fruits and stems.

The genotypes Maravilha and Preciosa had the largest amounts of $\mathrm{Ca}$ (calcium) to be returned to the soil (group a). Ca was the most accumulated macronutrient in the litterfall. This result is due to the low mobility of $\mathrm{Ca}$ in the phloem (MARSCHNER, 1995). The banana export only $4.7 \%$ of $\mathrm{Ca}$ absorbed in the fruits and the remainder $(95.3 \%)$, in the crop residues (leaves pseudostem, stem, bracts and flower debris), are reintroduced to the system (MOREIRA; FAGERIA, 2009).

The genotypes Maravilha, Pacovan-Ken and Preciosa had the largest accumulations of S (sulfur) and $\mathrm{Mg}$ (Magnesium) contents to be returned to the soil (group a). Busquet (2006), evaluated the nutrient accumulation in banana genotypes and found that the Prata-Anã genotype accumulated more $\mathrm{Mg}$ in the pseudostem, despite this element being considered of easy translocation in the plant. Hoffmann et al. (2010a) found higher $\mathrm{Mg}$ accumulation in the pseudostem, in cultivars Grand Naine $(31.36 \%)$ and Prata-Anã (42.94\%).

The genotypes that showed the highest $\mathrm{Mg}$ content in the present study (Maravilha, Pacovan- Ken and Preciosa) were the ones with largest pseudostem perimeter and higher heights. Symptoms of deficiency of $\mathrm{Mg}$ may occur by excessive potassium fertilization. This is an important aspect, since the banana requires high rates of K. Therefore, the nutrients present in the litterfall must be taking into account for fertilizer management to avoid overestimation.

Most of genotypes had the descending order $\mathrm{Ca}>\mathrm{N}>\mathrm{K}>\mathrm{Mg}>\mathrm{S}>\mathrm{P}$ for nutrient contents returned to the soil. Moreira and Fageria (2009) found nutrient contents in crop residues of banana trees with the descending order $\mathrm{Ca}>\mathrm{K}>\mathrm{S}>\mathrm{Mg}>\mathrm{N}>\mathrm{Na}>\mathrm{P}$. These result confirms the order found in the present study, especially for $\mathrm{Ca}$ and $\mathrm{P}$. 
These results show that the genotypes return the soil different amounts of macronutrients, mainly due to their different nutritional requirements and dry matter contents. Therefore, they must be fertilized differently to achieve a sustainable production system, which is not a common practice in in most regions.

Table 2. Macronutrient content returned to the soil by banana genotypes.

\begin{tabular}{lccrrrr}
\hline & \multicolumn{7}{c}{ Macronutrients $\left(\mathrm{kg} \mathrm{h}^{-1}\right)$} \\
\hline Genotypes & $\mathrm{N}$ & $\mathrm{P}$ & $\mathrm{K}$ & $\mathrm{Ca}$ & $\mathrm{S}$ & $\mathrm{Mg}$ \\
\hline Prata-Ana & $36.91 \mathrm{~b}$ & $4.21 \mathrm{~b}$ & $22.31 \mathrm{a}$ & $99.5 \mathrm{~b}$ & $5.72 \mathrm{~b}$ & $20.99 \mathrm{~b}$ \\
Maravilha & $62.87 \mathrm{a}$ & $7.45 \mathrm{a}$ & $30.38 \mathrm{a}$ & $142.24 \mathrm{a}$ & $10.93 \mathrm{a}$ & $34.29 \mathrm{a}$ \\
Fhia-18 & $24.69 \mathrm{~b}$ & $2.19 \mathrm{~b}$ & $11.65 \mathrm{~b}$ & $44.68 \mathrm{~b}$ & $3.31 \mathrm{~b}$ & $10.64 \mathrm{~b}$ \\
PA42-44 & $29.33 \mathrm{~b}$ & $3.66 \mathrm{~b}$ & $11.48 \mathrm{~b}$ & $89.40 \mathrm{~b}$ & $5.00 \mathrm{~b}$ & $20.15 \mathrm{~b}$ \\
PA94-01 & $26.9 \mathrm{~b}$ & $2.58 \mathrm{~b}$ & $7.01 \mathrm{~b}$ & $57.08 \mathrm{~b}$ & $4.59 \mathrm{~b}$ & $22.10 \mathrm{~b}$ \\
JV-42-135 & $45.47 \mathrm{~b}$ & $4.24 \mathrm{~b}$ & $10.09 \mathrm{~b}$ & $82.03 \mathrm{~b}$ & $6.62 \mathrm{~b}$ & $18.33 \mathrm{~b}$ \\
Pacovan & $32.84 \mathrm{~b}$ & $4.20 \mathrm{~b}$ & $22.01 \mathrm{a}$ & $61.65 \mathrm{~b}$ & $5.91 \mathrm{~b}$ & $16.30 \mathrm{~b}$ \\
Japira & $36.97 \mathrm{~b}$ & $3.73 \mathrm{~b}$ & $21.81 \mathrm{a}$ & $57.42 \mathrm{~b}$ & $4.35 \mathrm{~b}$ & $13.44 \mathrm{~b}$ \\
PV-79-34 & $36.89 \mathrm{~b}$ & $3.87 \mathrm{~b}$ & $14.84 \mathrm{~b}$ & $74.69 \mathrm{~b}$ & $6.87 \mathrm{~b}$ & $20.96 \mathrm{~b}$ \\
Pacovan-Ken & $55.49 \mathrm{a}$ & $7.01 \mathrm{a}$ & $29.46 \mathrm{a}$ & $99.44 \mathrm{~b}$ & $9.02 \mathrm{a}$ & $32.16 \mathrm{a}$ \\
Preciosa & $70.99 \mathrm{a}$ & $7.39 \mathrm{a}$ & $38.40 \mathrm{a}$ & $145.09 \mathrm{a}$ & $9.42 \mathrm{a}$ & $43.85 \mathrm{a}$ \\
Garantida & $42.59 \mathrm{~b}$ & $4.74 \mathrm{~b}$ & $14.00 \mathrm{~b}$ & $90.78 \mathrm{~b}$ & $7.58 \mathrm{a}$ & $20.33 \mathrm{~b}$ \\
\hline
\end{tabular}

Means followed by the same letters in the columns are from to the same group by the Scott-Knott criterion at $5 \%$ of probability.

Groups were formed only for the micronutrient $\mathrm{B}$ (Boron) and the element $\mathrm{Na}$ (Sodium) Na (Table 3). The estimated average of B accumulation in the litterfall ranged from 59.06 (PA42-44) to 206.49 (Maravilha) $\mathrm{g} \mathrm{ha}^{-1}$ forming two groups by the Scott-Knott criterion at $5 \%$ of probability. On average, a banana plant returns to the soil $222.8 \mathrm{~g}$ of B ha $^{-1}$ (BORGES et al., 2002). This nutrient is linked mainly to the reproduction process (MALAVOLTA et al., 2006), thus, the highest contents of $\mathrm{B}$ are probably in flower, buds and ovaries.

Fe was the most accumulated micronutrient in the litterfall. Hoffmann et al. (2010b) found 2,815.6 (Pacovan) and 2,123 (Prata-Anã) $\mathrm{g} \mathrm{ha}^{-1}$ of this nutrient in plant parts in the ground, very below the amounts found in the present work, which is probably due to soil remains that were in the litterfall collected, since the soil under the banana plants had a high content of this element $\left(11.85 \mathrm{mg} \mathrm{dm}^{-3}\right)$ (Table 1).

The accumulation of $\mathrm{Na}$ ranged from 892.06 to $5618.45 \mathrm{~g} \mathrm{ha}^{-1}$, with the genotypes Prata-Anã ,
Maravilha, JV-42-135, Pacovan- Ken and Preciosa grouping with the greatest contents. Moreira and Fageria (2009) evaluated the distribution and remobilization of nutrients in banana and found $45.21 \mathrm{~kg} \mathrm{ha}^{-1}$ of $\mathrm{Na}$ in various organs of the plant, and accumulation above $60 \%$ in the rhizome. The accumulation of sodium in the rhizome shows that banana roots are probably selective, storing the largest amount of this element, avoiding toxicity to the other organs. These results differ from those found in the present study, which had lower values, possibly because the rhizome is not part of the litterfall dry matter.

The descending order of micronutrient accumulation in the litterfall of the different banana genotypes was $\mathrm{Fe}>\mathrm{Mn}>\mathrm{Zn}>\mathrm{B}>\mathrm{Cu}$. Hoffmann et al. (2010b) found a different descending order $(\mathrm{Mn}>\mathrm{Fe}>\mathrm{B}>\mathrm{Zn}>\mathrm{Cu})$, except for $\mathrm{Cu}$. The export of micronutrients by the bunches, relative to the total absorbed, was $28 \%$ for B, $49 \%$ for $\mathrm{Cu}$ and $42 \%$ for Zn (BORGES, 2004), which explains the descending order of accumulation in the litterfall.

Table 3. Micronutrient and sodium contents returned to the soil by banana genotypes.

\begin{tabular}{lcrrrrr}
\hline & \multicolumn{6}{c}{ Micronutrients and Sodium $\left(\mathrm{g} \mathrm{ha}^{-1}\right)$} \\
\hline Genotypes & $\mathrm{B}$ & $\mathrm{Zn}$ & $\mathrm{Cu}$ & $\mathrm{Fe}$ & $\mathrm{Mn}$ & $\mathrm{Na}$ \\
\hline Prata-Ana & $114.0 \mathrm{~b}$ & $131.29 \mathrm{a}$ & $17.6 \mathrm{a}$ & $7608.35 \mathrm{a}$ & $512.44 \mathrm{a}$ & $3777.40 \mathrm{a}$ \\
Maravilha & $206.49 \mathrm{a}$ & $160.57 \mathrm{a}$ & $28.10 \mathrm{a}$ & $17629.32 \mathrm{a}$ & $904.50 \mathrm{a}$ & $4075.04 \mathrm{a}$ \\
Fhia-18 & $69.80 \mathrm{~b}$ & $65.0 \mathrm{a}$ & $9.67 \mathrm{a}$ & $4774.73 \mathrm{a}$ & $250.33 \mathrm{a}$ & $898.79 \mathrm{~b}$ \\
PA 42 44 & $86.69 \mathrm{~b}$ & $56.09 \mathrm{a}$ & $11.67 \mathrm{a}$ & $4537.89 \mathrm{a}$ & $435.34 \mathrm{a}$ & $1793.76 \mathrm{~b}$ \\
PA 94 01 & $59.06 \mathrm{~b}$ & $111.03 \mathrm{a}$ & $20.72 \mathrm{a}$ & $11253.52 \mathrm{a}$ & $568.00 \mathrm{a}$ & $1862.61 \mathrm{~b}$ \\
$J V-42-135$ & $88.23 \mathrm{~b}$ & $150.67 \mathrm{a}$ & $23.18 \mathrm{a}$ & $9160.61 \mathrm{a}$ & $804.73 \mathrm{a}$ & $3271.11 \mathrm{a}$ \\
\hline
\end{tabular}

Means followed by the same letters in the columns are from to the same group by the Scott-Knott criterion at $5 \%$ of probability. 
Table 3. Continuation.

\begin{tabular}{lrrrrrr}
\hline & \multicolumn{6}{c}{ Micronutrients and Sodium $\left(\mathrm{g} \mathrm{ha}^{-1}\right)$} \\
\hline Genotypes & \multicolumn{1}{c}{$\mathrm{B}$} & \multicolumn{1}{c}{$\mathrm{Zn}$} & $\mathrm{Cu}$ & \multicolumn{1}{c}{$\mathrm{Fe}$} & $\mathrm{Mn}$ & $\mathrm{Na}$ \\
\hline Pacovan & $111.14 \mathrm{~b}$ & $96.17 \mathrm{a}$ & $10.12 \mathrm{a}$ & $6409.97 \mathrm{a}$ & $483.21 \mathrm{a}$ & $1628.26 \mathrm{~b}$ \\
Japira & $80.63 \mathrm{~b}$ & $69.41 \mathrm{a}$ & $11.86 \mathrm{a}$ & $6949.51 \mathrm{a}$ & $269.87 \mathrm{a}$ & $892.06 \mathrm{~b}$ \\
PV-79-34 & $98.92 \mathrm{~b}$ & $145.71 \mathrm{a}$ & $16.29 \mathrm{a}$ & $13100.03 \mathrm{a}$ & $613.46 \mathrm{a}$ & $1469.46 \mathrm{~b}$ \\
Pacovan-Ken & $166.98 \mathrm{a}$ & $110.23 \mathrm{a}$ & $25.31 \mathrm{a}$ & $8167.87 \mathrm{a}$ & $713.35 \mathrm{a}$ & $5618.45 \mathrm{a}$ \\
Preciosa & $194.20 \mathrm{a}$ & $141.77 \mathrm{a}$ & $20.14 \mathrm{a}$ & $11105.74 \mathrm{a}$ & $707.33 \mathrm{a}$ & $4092.64 \mathrm{a}$ \\
Garantida & $110.21 \mathrm{~b}$ & $109.55 \mathrm{a}$ & $18.18 \mathrm{a}$ & $9424.23 \mathrm{a}$ & $532.29 \mathrm{a}$ & $2213.44 \mathrm{~b}$ \\
\hline
\end{tabular}

Means followed by the same letters in the columns are from to the same group by the Scott-Knott criterion at $5 \%$ of probability.

\section{CONCLUSION}

The banana genotypes Preciosa, Maravilha and Pacovan-Ken produced the greatest contents of litterfall, and their chemical characterization shows the descending order $\mathrm{Ca}>\mathrm{N}>\mathrm{Mg}>\mathrm{K}>\mathrm{S}>\mathrm{P}$ for macronutrients and $\mathrm{Fe}>\mathrm{Mn}>\mathrm{B}>\mathrm{Zn}>\mathrm{Cu}$ for micronutrients.

The banana genotypes $P V-79-34$, Garantida, Pacovan, JV-42-135, Prata-Anã, Pacovan-Ken, Preciosa and Maravilha present the lowest number of days for decomposition of the litterfall accumulated.

\section{REFERENCES}

ALVES, A. R. et al. Aporte e decomposição de serapilheira em área de Caatinga, na Paraíba. Revista de Biologia e Ciências da Terra, João Pessoa, v. 6, n. 2, p. 194-203, 2006.

ARATO, H. D.; MARTINS, S. V.; FERRARI, S. H. S. Produção e decomposição de serapilheira em um sistema agroflorestal implantado para recuperação de área degradada em Viçosa-MG. Revista Árvore, Viçosa, v. 27, n. 5, p. 715-721, 2003.

AZEVEDO, V. F. et al. Avaliação de bananeiras tipo Prata, de porte alto, no Semiárido. Ciência e Agrotecnologia, Lavras, v. 34, n. 6, p. 1372 $\square 1380$, 2010.

BORGES, A. L. Calagem e adubação. In: BORGES, A. L.; SOUZA, L. S. (Eds. 1). O cultivo da bananeira. Cruz das Almas: Embrapa Mandioca e Fruticultura, 2004. v. 1, cap. 3, p. 32-44.

BORGES, A. L. et al. Nutrição e adubação da bananeira irrigada. Cruz das Almas: Embrapa Mandioca e Fruticultura, 2002. 8 p. (Circular Técnica, 48).

BRUN, E. J.; FERRAZ, M. O.; ARAÚJO, E. F. Relação entre o acúmulo de serapilheira sobre o solo e variáveis dendrométricas em povoamento híbrido de Eucalyptus urophylla x E. globulus maidenii, em Eldorado do Sul/RS. Ecologia e Nutrição Florestal, Santa Maria, v. 1, n. 1, p. 24-31, 2013.

BUSQUET, R. N. B. Análise de crescimento, fenologia e acumulação de nutrientes de quatro genótipos de bananeira no estado do Rio de Janeiro. 2006. 101 f. Tese (Doutorado em Fitotecnia: Área de Concentração em Produção Vegetal) - Universidade Federal Rural do Rio de Janeiro, Rio de Janeiro, 2006.

DONATO, S. L. R. et al. Comportamento fitotécnico da bananeira 'Prata-Anã' e de seus híbridos. Pesquisa Agropecuária Brasileira, Brasília, v. 44, n. 12, p. 1608-1615, 2009.

DONATO, S. L. R. et al. Estado nutricional de bananeiras tipo prata sob diferentes sistemas de irrigação. Pesquisa Agropecuária Brasileira Brasília, v. 45, n. 9, p. 980-988, 2010.

FAO. Agricultural production, primary crops. Disponível em: <http://www.faostat.fao.org/site/567/ default.aspx.>. Acesso em: 02 jun. 2016.

GAMA-RODRIGUES, A. C.; BARROS, N. F. Ciclagem de nutrientes em floresta natural e em plantios de eucalipto e de dandá no sudeste da Bahia, Brasil. Revista Árvore, Viçosa, v. 26, n. 2, p. 193207, 2002.

HOFFMANN, R. B. et al. Acúmulo de matéria seca, absorção e exportação de micronutrientes em variedades de bananeira sob irrigação. Ciência e Agrotecnologia, Lavras, v. 34, n. 3, p. 536-544, $2010 b$

HOFFMANN, R. B. et al. Acúmulo de matéria seca e de macronutrientes em cultivares de bananeira irrigada. Revista Brasileira de Fruticultura, Jaboticabal, v. 32, n. 1, p. 268-275, 2010a.

LOPES, M. C. A.; ARAÚJO, V. F. P.; VASCONCELLOS, A. The effects of rainfall and 
vegetation on litterfall production in the semiarid region of northeastern Brazil. Brazilian Journal of Biology, São Carlos, v. 75, n. 3, p. 703-708, 2015.

MALAVOLTA, E. Manual de nutrição mineral de plantas.1. ed. Piracicaba, SP: Agronômica Ceres, 2006. $631 \mathrm{p}$.

MALAVOLTA, E.; VITTI, G. C.; OLIVEIRA, S. A. Avaliação do estado nutricional das plantas: princípios e aplicações. 2. ed. Piracicaba, SP: Associação Brasileira para Pesquisa da Potassa e do Fosfato, 1997, $201 \mathrm{p}$.

MARSCHNER, H. Mineral nutrition for higher plants. London: Academic Press, 1995. 889 p.

MOREIRA, A.; FAGERIA, N. K. Repartição e remobilização de nutrientes na bananeira. Revista Brasileira de Fruticultura, Jaboticabal, v. 31, n. 2, p. 574-581, 2009.

OLSON, J. S. Energy storage and the balance of producers and decomposers in ecological systems. Ecology, Tempe, v. 44, n. 2, p. 322-331, 1963.

OZIEGBE, M. B.; MUOGHALU, J. I.; OKE, S. O. Litterfall, precipitation and nutrient fluxes in a secondary lowland rain forest in Ile-Ife, Nigeria. Acta Botanica Brasilica, Belo Horizonte, v. 25, n. 3, p. 664-671, 2011.

PEREIRA, M. G. et al. Aporte e decomposição de serapilheira em floresta periodicamente inundável na restinga da Marambaia, RJ. Ciência Florestal, Santa Maria, v. 22, n. 1, p. 59-67, 2012.

PIMENTA, J. A. et al. Produção de serapilheira e ciclagem de nutrientes de um reflorestamento e de uma floresta estacional semidecidual no sul do Brasil. Acta Botanica Brasilica, Belo Horizonte, v. 25, n. 1, p. 53-57, 2011.

R DEVELOPMENT CORE TEAM, R. A language and environment for statistical computing, Vienna, Austria: R Foundation for Statistical Computing. Disponível em: $<$ http://www.Rprojetc.org.>. Acesso em: 08 set. 2015.

SHANKS, R.; OLSON, J. First-year breakdown of leaf litter in Southern Appalachian Forests. Sciense, New York, v. 134, n. 3473, p. 194-195, 1961.

SILVA, H. F. et al. Decomposição de serapilheira foliar em três sistemas florestais no Sudoeste da Bahia. Revista Brasileira de Biociências, Porto Alegre, v. 12, n. 3, p. 164-172, 2014.

SOARES F. A. L. et al. Acúmulo de matéria seca e distribuição de nutrientes em duas cultivares de bananeiras irrigadas com água moderadamente salina. Revista Brasileira de Ciências Agrárias, Recife, v. 6, n. 2, p. 321-330, 2011.

TANGJANG, S. et al. Litterfall, Decomposition and Nutrient Dynamics in Traditional Agro-Forestry Systems of Northeast India. Ecology and Environmental Sciences, New Delh, v. 41, n. 1-2, p. 43-53, 2015.

TERROR, L. L.; SOUSA, H. C.; KOZOVITS, A. R. Produção, decomposição e qualidade nutricional da serapilheira foliar em uma floresta paludosa de altitude. Acta Botanica Brasilica, Belo Horizonte, v. 25, n. 1, p. 113-121, 2011.

VIERA, M. et al. Nutrientes na serapilheira em um fragmento de floresta estacional. Ciência Florestal, Santa Maria, v. 20, n. 4, p. 611-619, 2010.

WHITE, B. L. A. et al. Dynamics of the production and decomposition of litterfall in a brazilian northeastern tropical forest (Serra de Itabaiana National Park, Sergipe State). Acta ScientiarumBiological Sciences, Maringá, v. 35, n. 2, p. 195-201, 2013. 